\title{
La conciencia de la nihilidad en la poesía de Contemporáneos. Para una hermenéutica de la muerte en la poesía mexicana ${ }^{1}$
}

\section{Rebeca Maldonado}

...la esencia de la poesía descansa en el pensar ...porque, por su esencia, es, desde siempre y para siempre, lo más digno de ser pensado...

Martin Heidegger

...la poesía, para mí, es una investigación de ciertas esencias - el amor, la vida, la muerte, Dios-que se produce en un esfuerzo por quebrantar el lenguaje de tal manera que, haciéndolo más transparente, se pueda ver a través de él dentro de esas esencias.

José Gorostiza

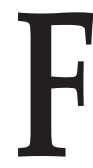

\section{ilosofar desde la propia lengua}

Cuando José Gorostiza escribe "el espíritu no nos pertenece ni nos pertenecerá mientras la forma no se anime con la poesía del suelo", ${ }^{2}$ dirige una crítica a la poesía que escrita en México y en español lo hace apropiándose de la cultura, de la lengua y la geografía de otras latitudes.Sin lugar a dudas, esta consideración abre posibilidades a la filosofía escrita en México y en español. Para Gorostiza la filosofía y la misma poesía han de sustentarse en la poesía del suelo y hacerse desde nuestro propio idioma. Tan importante es la lengua, que Octavio Paz lanza una propuesta hermenéutica fundamental: "una tradición poética no se define por el concepto político de nacionalidad sino por la lengua y por las relaciones que se tejen entre los estilos y los creadores". ${ }^{3}$ Existe, así, una cierta insustituibilidad de la propia lengua y de

${ }^{1}$ Este trabajo se hizo con el apoyo de la beca posdoctoral otorgada por el PROFIP de la Dirección General de Apoyo al Personal Académico de la UNAM, de marzo de 2007 a marzo de 2009.

${ }^{2}$ José Gorostiza, "Ramón López Velarde y su obra", en Poesía y prosa. Ed. de Miguel Capistrán y Jaime Labastida. México, Siglo XXI, 2007, p. 248.

3 Octavio Paz, “'Xavier' se escribe con equis", en Generaciones y semblanzas. México, FCE/Círculo de Lectores, 1994, p. 252. 
sus producciones que afecta al pensamiento mismo. ${ }^{4}$ En este texto se trata de hacer filosofía desde la creación poética en la propia lengua. Pero ¿qué dicen nuestros poetas de la poesía? Octavio Paz en ¿Águila o sol? piensa que la poesía realiza una necesaria labor destructora del lenguaje, y en esa tarea permite "ver el mundo de afuera", 5 pero mientras no sea así, "las palabras mueren de sed". 6 "Palabras, palabras de un cuarto de hora arrancado al árbol calcinado del lenguaje, entre los buenos días y las buenas noches, puertas de salida y de entrada de un corredor que va a ningunaparte a ningunlado". ${ }^{7}$ Lo que la filosofía recoge, cuando se acerca a la poesía, es entonces un lenguaje decantado, un lenguaje transfigurado, un lenguaje que sólo renacido permite ver. José Gorostiza también pensará que el poeta quebranta el lenguaje, lo pulveriza, para hacer ver a través de él ciertas esencias, es decir, para hacer ver modos de ser. ${ }^{8}$ Por lo tanto, acercarse a la poesía desde la filosofía no puede hacerse a espaldas de la metafísica occidental y de las diferentes críticas a la metafísica, pues sólo en ellas coaguló la conciencia ontológica, al punto de considerar el problema del ser en el centro de la filosofía. Más aún, en este ensayo se propone un acercamiento a la poesía de la muerte en Gorostiza, Villaurrutia y Ortiz de Montellano, porque esta multiplicidad de voces unidas por amistad y vocación avistó además la finitud dentro de la amplia región del ser. Su poesía dedicada a la muerte abre al pensar porque al tiempo que marca en el lenguaje una coloratura, un tono, un estilo, una cadencia, abre ámbitos desacostumbrados de consideración de las cosas, las muestra ahora sí en su verdadero modo de ser.

Al pensar en cercanía con la poesía, acontece, ciertamente, "la instauración del ser con la palabra", en el sentido de "fundamentación de la existencia humana en su razón de ser", 9 como pensó Heidegger, pero la radicalidad de

${ }^{4}$ Gadamer comenta sobre la filosofia que emerge de las producciones de la propia lengua a propósito de Heidegger: porque el "pensar está aliado con la lengua realmente hablada. Ella nos ofrece nuestra experiencia del pensar y esto se aplica de hecho a todas las lenguas habladas [...] como lenguas habladas también han encontrado sus propias posibilidades de articulaciones conceptuales y también nos permiten entrever futuras experiencias del pensar" (Hans-Georg Gadamer, Los caminos de Heidegger. Barcelona, Herder, 2002, p. 317). No hay que olvidar que este comentario es válido para Gadamer, quien hizo ensayos de este tipo a partir de textos de la poesía de Celan y Trakl.

${ }^{5}$ O. Paz, "¿Águila o sol?”, en Obra poética I. México, FCE, 1997, p. 157.

${ }^{6}$ Ibid., p. 154.

${ }^{7}$ Ibid., p. 152.

${ }^{8}$ Tema del siguiente apartado.

${ }^{9}$ M. Heidegger, "Hölderlin y la esencia de la poesía", en Arte y poesía. México, FCE, 1992, p. 137. Más adelante encontramos: "Lo que dicen los poetas es instauración, no sólo en el sentido de donación libre, sino a la vez en sentido de firme fundamentación de la existencia humana en su razón de ser. [...] puesto que el ser y la esencia de las cosas 
la fundamentación de la existencia humana en la poesía de la muerte es mayor, porque ella conducirá a las únicas condiciones verdaderas de existencia, conducirá a la existencia a su razón de ser: al vacío y la nada emergiendo en el seno mismo del ente, siendo ambos fuerza de aclaración del ser (nihilismo propio). ${ }^{10}$ Sólo la nada abre el camino, sólo ella enseña a echar a un lado esa continua interposición del ente. Entre nosotros está lo ente, puesto en medio, una y otra vez, como forma. Si se escuchara la poesía mexicana de la muerte, ya sin entes, no aparecerá sino una aclaradora nada. Durante el siglo xx artistas, pensadores y poetas, realizaron un descenso a la nada. Lo hicieron Lispector, Rothko, Cage, Heidegger, Nishida y Zambrano, entre otros. María Zambrano precisamente pensó que la nueva forma de lo sagrado era la nada. Declara María Zambrano en El hombre y lo divino: "El fondo sagrado reaparece ahora en la nada”. ${ }^{11} \mathrm{Y}$ ¿qué es lo sagrado? Lo sagrado en Zambrano es el principio de realidad anterior de la razón, lo sagrado hace que la realidad no sea "atributo ni cualidad [...]: es algo anterior a las cosas, es una irradiación de la vida que emana de un fondo de misterio; es la realidad oculta, escondida; corresponde en suma, a lo que hoy llamamos sagrado". ${ }^{12}$ La nada, al dejar a un lado toda resistencia, abre el camino a lo vivo esencial. Pero, mientras no es así, vivimos en una noche oscura y en esta cerrada noche (nihilismo impropio), perdidos en medio de lo ente, la poesía se yergue como un faro. En un poema mínimo, Gorostiza escribe "El faro/ rubio pastor de barcas pescadoras". ${ }^{13}$ Debemos prestar atención a este faro pastor de barcas pescadoras que es el poeta, porque la poesía alumbra las claves de nuestro destino y constituye una forma de realización de la conciencia histórica. Desde la oscuridad más extrema, es decir, desde la conciencia más extrema del nihilismo, en la poesía acontece un nuevo modo de darse del ser. La poesía de Gorostiza, Villaurrutia y Ortiz de Montellano interpela a la filosofía, porque en la medida que ilumina un modo

no pueden ser calculados ni derivados de lo existente, deben ser libremente creados, puestos y donados. Esta libre donación es instauración" (ibid., p. 138).

${ }^{10}$ Sobre la distinción nihilismo propio y nihilismo impropio de Heidegger, $c f$. M. Heidegger, "La determinación del nihilismo según la historia del ser", en Nietzsche II. Barcelona, Destino, 2000, cap VII, pp. 289-293. Luis Sáez Rueda dice al respecto: "distingue el filósofo entre el nihilismo en sentido impropio, que abandona el ser, negándolo como pura nada, y el nihilismo en sentido propio, que acoge y se tiene a la indisponibilidad del ser, salvaguardando el encubrimiento. Este último nihilismo expresa la experiencia más profunda de la verdad del ser: la nada de lo ente como plenitud del misterio que se reserva" (Luis Sáez Rueda, "La tarea del pensar en tiempos del nihilismo. Hermenéutica, diferencia y tragedia”, en Raúl Alcalá Campos y Jorge Armando Reyes Escobar, Gadamer y las humanidades II. México, unAm, Facultad de Filosofía y Letras, 2007, p. 136.

${ }^{11}$ María Zambrano, El hombre y lo divino. Madrid, Siruela, 1991, p. 170.

12 Ibid., p. 34.

${ }^{13}$ J. Gorostiza, "Dibujos sobre un puerto", en Poesía y prosa, p. 84. 
de darse el ser, abre un lugar de pensamiento. Este trabajo se acerca a la poesía de Villaurrutia y Gorostiza, es decir, a Nostalgia de la muerte (1938) del primero y a Muerte sin fin (1939) del segundo, con el fin de elaborar una hermenéutica de la muerte que sirva de tránsito a una ontología de la muerte. Entendemos por hermenéutica de la muerte la dilucidación de un conjunto de textos que tienen como ámbito de su despliegue la muerte y el vacío. En la poesía de Gorostiza, Villaurrutia y Ortiz de Montellano acontece una confluencia entre filosofía y poesía, y, para quien aquí escribe, es en la poesía donde está nuestra acaecida conciencia filosófica, y, a decir de Pedro Cerezo, eso pasa en toda Iberoamérica, es decir, "la filosofía está enterrada en la poesía". ${ }^{14}$ No es que en Iberoamérica no haya filosofía, nuestra poesía es el lugar donde el pensamiento pudo respirar, donde al fin el pensamiento encontró el ámbito de su crecimiento y despliegue, es decir, alas. ${ }^{15}$

Ahora ¿cómo la poesía mexicana de la muerte, tan arraigada inmemorialmente en nuestra conciencia, actualiza tan arriesgada tentativa? Ella toca el vértice de la vida, como piensa Paz, pero para luego sentir el jade que se rompe, el plumaje que se desgarra o cómo "las formas sangran" como sucede con Gorostiza. ${ }^{16}$ La poesía de la muerte mexicana se enfrenta a ese gran men-

${ }^{14}$ En noviembre de 2008, al conversar con el filósofo español Pedro Cerezo en la Universidad de Granada sobre estos temas, mientras yo afirmaba que la conciencia filosófica de México estaba en la poesía, él hace mi afirmación aún más contundente: "eso pasa en todo Iberoamérica, la filosofía está enterrada en la poesía”. Ahondar en este hecho me parece una de las tareas importantes de la filosofía en Iberoamérica.

${ }^{15}$ Para ser breve, Contemporáneos en un sentido es el nombre de la revista literaria fundada entre los años de 1928-1931, dirigida por Bernardo Ortiz de Montellano, y, en otro, es el grupo intelectual congregado en torno a dicha revista. Guillermo Sheridan distingue dos promociones en dicho grupo: la primera, nacida entre 1898 y 1901, comprendida por Bernardo Ortiz de Montellano, Enrique González Rojo, Jaime Torres Bodet y José Gorostiza y, la segunda, nacida entre 1901 y 1905, por Jorge Cuesta, Gilberto Owen, Xavier Villaurrutia y Salvador Novo. De ese grupo, además de los mencionados, formó parte también Carlos Pellicer. Este grupo buscaba rebasar el modernismo cargado de ornamentación según la sentencia de Enrique González Martínez: "tuércele el cuello al cisne de engañoso plumaje" y para ello, piensa Gorostiza, recurrieron al rigor de la disciplina y de la crítica. Como veremos al final del recorrido de este ensayo, en la poética de Contemporáneos el giro de la ornamentación y la retórica acontece por el silencio y el vacío desde donde se emite la voz poética (Guillermo Sheridan, "José Gorostiza entre los Contemporáneos", en José Gorostiza, Poesía y poética. Ed. de Edelmira Ramírez. México, Conaculta, 1989, pp. 158-159).

${ }^{16}$ El conocido poema de Nezahualcóyotl es: "Nos iremos, ay... igozaos!/ Lo digo yo, Nezahualcóyotl./ Es que acaso se vive de verdad en la tierra?/ ¡No por siempre en la tierra,/ sólo brevemente aquí!/ Aunque sea jade: también se quiebra;/ aunque sea oro, también se hiende,/ y aun el plumaje de quetzal se desgarra:/ ¡No por siempre en la tierra:/ sólo breve tiempo aquí!" (Cf. José Luis Martínez, Nezahualcóyotl, vida y obra. México, FCE, 1972, p. 186). 
tís que es la vida. Su obsesión es ese quiebre o vértice donde aparece la vida muriéndose, la muerte viva. En ella se abre una nueva comprensión, la muerte no es un más allá de la vida, ni un concepto abstracto, es vida muriéndose en las entrañas de todo, en el seno mismo de la inmanencia. En ella acontece, por tanto, el quiebre del ser; en ella, se deja estar obnubilado y cegado por el ser, porque en ella acontece una comprensión: la muerte misma, el vacío y la nada se muestran en contemporaneidad con el ser y, por lo mismo, no entiende el ente ahíto de ser, absuelto de la nada, sino la nada en mismidad con el ser. La vida para estos poetas es una contradictio in terminis: la vida es un oxímoron, un nacer-morir, muriéndose ser. Gorostiza lo dice en una entrevista: "Muerte sin fin me nació un día en que me sentí llamado en mi atención por el proceso de la vida y de la muerte, y advertí que todo lo que nosotros vemos está naciendo y muriendo al mismo tiempo". ${ }^{17}$ Ortiz de Montellano nos dice en Muerte de cielo azul: "El cuerpo [...] sabe lo difícil que es separar la vida y la muerte, lo orgánico y lo inorgánico, lo que le pertenece y lo que es nada más su profunda oscuridad; límites que se mezclan, a menudo, para producir la riqueza de la vida, su aparente desorganización y la belleza" ${ }^{18}$ Es más, la poesía es la única actividad que permite entender la vida sin separarla de la muerte, sin separar el ser de la nada, porque para la poesía, piensa Ortiz de Montellano, en la profunda oscuridad "están la vida y la muerte, el cuerpo y lo que no es el cuerpo inseparablemente juntos". ${ }^{19}$ En Contemporáneos coaguló poéticamente la idea de que la vida se da en contemporaneidad con la muerte, el ser en contemporaneidad con la nada, y que el poeta es el llamado a hollar en esa interpenetración, mientras que el hombre ordinario en lugar de captar su interpenetración capta su oposición. En el último poema de Muerte de cielo $a z u l$, intitulado "A la alegría de la vida y de la muerte", leemos:

Espíritu que nace de lo inerte negación de placer, cuerpo dormido indolente conciencia del sentido que goza de la rosa de la muerte

${ }^{17}$ Citado por Guillermo Sheridan, "José Gorostiza en sus cartas”, en José Gorostiza, Epistolario (1918-1940). Ed. de Guillermo Sheridan, María Isabel Torre de Suárez y María Isabel González de la Fuente. México, Conaculta, 1995, p. 26. Quiero agregar una afirmación de Gorostiza que aparece en una carta dirigida a Francisco Orozco Muñoz y que éste reproduce en la contestación a Gorostiza: "Sí, está usted en lo cierto. 'Saber que estamos muriendo a cada paso' es lo que me ha hecho hacer versos" (J. Gorostiza, Epistolario..., p. 291).

${ }^{18}$ Bernardo Ortiz de Montellano, Obra poética. México, unAM, 2005, p. 215.

${ }^{19}$ Idem. 
Otro placer sin sombra ¿quién advierte?

¿quién muda de color, descolorido,

sin sentir en la sangre que lo ha herido

el paso sigiloso de la muerte?

Y si ese labio calla y otro miente

Y es el cuerpo la letra y la medida

$\mathrm{Y}$ el arte de morir es inconsciente

Color el agua sangre y no deserte

Que al fuego de la sombra de la vida

No se escape mi sombra de la muerte.

La matriz única de la vida-muerte constituye esencia última, y entiendo por esencia el sentido de Gorostiza, es decir, algo mil veces decantado por el silencio. ${ }^{20}$ Así como Ortiz de Montellano piensa al soneto como "la forma lírica de la definición", ${ }^{21}$ nosotros podemos decir, el poema, ya sea por la vía del soneto en Ortiz de Montellano o del nocturno en Villaurrutia, es la vía para captar aquella esencia última: la vida muriéndose. ${ }^{22}$

\section{Villaurrutia: la muerte es todo esto y más que nos circunda}

Hemos empleado la palabra "ente" y hemos tratado de esbozar con ello un modo de ser determinante de Occidente, que si ha llegado a ser destinal es porque desde los griegos imperó el horizonte del desocultamiento, porque ente desde Grecia, según Heidegger, fue lo desocultado mismo: lo desoculto. En Las preguntas fundamentales de la filosofía nos dice Heidegger: "Los griegos preguntan por el ente, qué sea éste como tal, y responden: estar desocultado".

Los griegos experimentaron y pensaron el ente en cuanto tal como lo estable tanto en el sentido de lo que está en sí, como también en

${ }^{20}$ Sobre este tema volveremos al final.

${ }^{21}$ B. Ortiz de Montellano, op. cit., p. 215.

${ }^{22}$ Según Ramón Xirau, "el concepto español de la muerte es finalista y no inmanentista como el mexicano. De las danzas de la muerte, de las Coplas de Jorge Manrique hasta Unamuno, García Lorca o Miguel Hernández el sentimiento español de la muerte da presencia a la vida y se proyecta hacia un más allá futuro sin olvidarse del mundo que le rodea" (Ramón Xirau, Tres poetas de la soledad. México, Antigua Librería Robredo, 1955, p. 32). 
el significado de lo que dura. El ente es para los griegos lo presente,

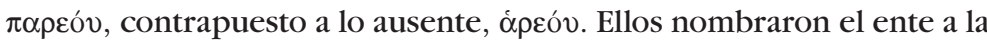
forma, en contraposición a la deformación. Para ellos ente es lo que limita en contraposición a lo ilimitado y lo que transcurre. [...] El carácter fundamental del ente como tal es esto que brota, se despliega, se impone: lo desocultado. ${ }^{23}$

Un azaroso destino hizo que esta oscilante diferencia entre lo oculto y lo desoculto (inicio del pensamiento occidental) se desdibujara, porque aunque ahí, en ese comienzo griego, también se oculta otra posibilidad, la cual dejamos en suspenso un momento, a partir de este reconocimiento del ente como lo desoculto, el pensamiento tomó un camino inverso al desocultamiento; al preguntarse por la unidad de la totalidad del ente, el ente se pensó como "naturaleza”, algo determinable por la razón a manera del cálculo y del dominio. Sin embargo, ¿por qué la poesía puede ubicarse en un preguntar más inicial? Y ¿por qué en la poesía la pregunta por el ente puede resonar de otra manera? Porque la poesía apunta a lo otro del ente, porque la poesía nombra la ausencia, porque la pregunta nombra la esencia de lo desocultado y sabe que el ente nunca es un ente y, en este sentido, apunta a la esencia de la verdad (es decir, a la esencia de la alétheia). Si para Heidegger, en la historia de Occidente, el ser se confundió con el ente y se caracterizó por un ir en pos del ente, en un contramovimiento; Villaurrutia, Gorostiza y Ortiz de Montellano, cada uno a su manera, trazan un itinerario de disolución del ente, entendido como lo que permanece y perdura, hasta concluir en el silencio, hasta volver con la palabra imposible la palabra. Ellos dejarán en claro que por intercesión de la nada el ser nunca es un ente y que el ente se muestra en su verdadero modo de ser al ponerse en relación con la nada; sólo entonces puede "acaecer-algoque nunca ha acaecido". ${ }^{24}$ Precisamente, en Preguntas fundamentales de la filosofía Heidegger dirá que la necesidad del no, la necesidad del "rehusamiento, aplazamiento y negación" se mostrará más esencialmente en ese ámbito o espacio donde acontece "no-saber-salir-ni-entrar"

[...] este "espacio" no transitado y no fundado. Este "espacio" [...] es aquel "entre" en el cual no está determinado lo que es y lo que no es, y en donde sin embargo la completa confusión de la no diferenciación del ente y el no-ente ya no arrebata todo y lo trae de aquí para allá. Esta necesidad, como tal el no-saber-salir-ni-entrar en este "entre" que se

${ }^{23}$ M. Heidegger, Preguntas fundamentales de la filosofía. Granada, Comares, 2008, p. 128.

${ }^{24}$ Cf. ibid., p. 133. 
inaugura a sí mismo, es una forma del "ser", en la que el ser humano alcanza o quizás es arrojado y por primera vez experimenta [...] lo que llamamos [estar] en medio del ente. ${ }^{25}$

Pero este estar en medio del ente, en medio de la no determinación entre el es y el no es "es más difícil de soportar que cualquier pérdida". ${ }^{26}$ Por eso también podemos decir, no fuera del ente, sino en el ente mismo, que el ser humano entra al espacio no decidido entre lo que es y no es: "el ser humano al crear se sobrepasa y retorna mediante el ente a la verdad del ser". ${ }^{27}$ La poesía es ingreso radical a ese espacio entre el ente y el no ente y, en consecuencia, al 'entre' como lugar del asombro.

Con Nostalgia de la muerte, Xavier Villaurrutia será el poeta que nos hará ver que el ente nunca es un ente, que tras él está lo oscuro, la sombra, el silencio, la muerte. A esta experiencia de pérdida de contornos y de no existir nada definido, Villaurrutia le nombra "naufragio invisible" en el poema Nocturno solo.

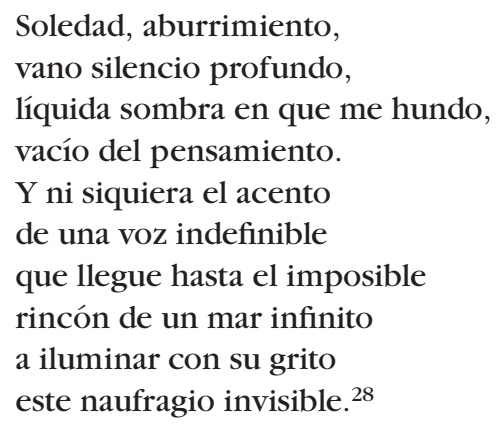

En este espacio entre el ser y el no ser todo lo ordinario pierde contundencia, se convertirá en sombra. "La muerte es todo esto y más que nos circunda", dice el poeta en Nocturno de la alcoba. Es decir, la muerte es lo que rodea a todas las cosas, su verdadera realidad; las cosas no están sustentadas en ellas mismas sino en algo que las trasciende, las rompe y las diluye; de esta manera acontece el movimiento poético de ir más allá de lo ente. La muerte, nos anuncia el poeta, "es cóncava y oscura y tibia y silenciosa, / se pliega en las

${ }^{25}$ Ibid., p. 142.

${ }^{26}$ Ibid., p. 143.

${ }^{27}$ Idem.

${ }^{28}$ Xavier Villaurrutia, "Nostalgia de la muerte", en Obras, poesía, teatro, prosas varias, crítica. México, FCE, 2006, pp. 50-51. 
cortinas en que anida la sombra". La muerte en Villaurrutia no es una muerte vegetal, corporal, animal que recorre lo vivo y lo aniquila rítmicamente sin distingos, como en Gorostiza; no, la muerte en Villaurrutia acontece ya en la intimidad con las cosas y con el otro, convierte a la intimidad en experiencia misma de la disolución. Nocturno es la experiencia poética de este no estar en casa, no estar al fin bajo sábanas y en descanso, no. Pues incluso, ya ahí, bajo las sábanas se sabe que el yo nunca es el yo, de la misma manera en que sabe que el ente nunca es un ente.

Al fin llegó la noche con sus largos silencios, con las húmedas sombras que todo amortiguan. El más ligero ruido crece de pronto y, luego, muere sin agonía.

El oído se aguza para ensartar un eco lejano, o el rumor de unas voces que dejan, al pasar, una huella de vocales perdidas.

¡Al fin llegó la noche tendiendo cenicientas alfombras, apagando luces, ventanas últimas!

Porque el silencio alarga lentas manos de sombra. La sombra es silenciosa, tanto que no sabemos dónde empieza o acaba, ni si empieza o acaba.

Y es inútil que encienda a mi lado una lámpara: la luz hace más honda la mina del silencio y por ella desciendo, inmóvil, de mí mismo. ${ }^{29}$

No hay duda implacable sobre las cosas que no se convierta a su vez en una duda profunda sobre el yo, pues, aunque si bien, sombra, noche, sueño, todos nombres de la oscuridad, son transiciones a la nada, pasos indispensables para la pérdida del poder terrestre, la nihilidad, como potencia, no descansa sino hasta abarcar al sujeto interrogante. La verdadera potencia no es la del cálculo, a la cual el sujeto del racionalismo pronto se allega, volviéndolo a él mismo más seguro y estable, sino la potencia de la nihilidad que tras la pérdida de consistencia de lo que aparentemente era consistente vuelve incluso al yo imposible. El verdadero y único personaje poético es la nada y el vacío,

${ }^{29}$ Ibid., p. 53. 
la nada ha tomado el lugar de un yo presunto. Ramón Xirau en Tres poetas de la soledad advierte este proceso de desrealización radical en Villaurrutia a través de la cual el poeta "se ausenta de las cosas al huir la conciencia de la sustancia que le es propia". ${ }^{30} \mathrm{Al}$ desarraigo de este mundo en virtud del proceso de desrealización le sigue "una soledad extremosa, la experiencia de un total desarraigo de la conciencia misma, de una despersonalización radical". ${ }^{31} \mathrm{El}$ paisaje de Villaurrutia está arrasado por la muerte y por la nada, se comprende porque para el mismo Gorostiza la poesía de Villaurrutia deja "ese extraño sabor a 'naturaleza muerta'".32

Villaurrutia fue totalmente seducido por la nada, fue literalmente tomado por ella y, como en Juan de la Cruz, es el lenguaje del deseo lo que lo hace entrar en la zona de la disolución, aunque para él todo lo vital esencial -la sangre, el deseo, la saliva- emana, nace y emerge desde el fondo oscuro: vive con mis ojos muertos / muere en mis labios duros. Todo ello es junto con la muerte y emana de lo que no tiene sustancia: la sombra y el sueño. Leemos en "Nocturno", poema que abre Nostalgia de la muerte:

Todo lo que la noche

dibuja con su mano

de sombra:

el placer que revela,

el vicio que desnuda.

Todo lo que la sombra

hace oír con el duro

golpe de su silencio:

las voces imprevistas

que a intervalos enciende,

el grito de la sangre,

el rumor de unos pasos

perdidos.

Todo lo que el silencio

hace huir de las cosas:

el vaho del deseo,

el sudor de la tierra,

${ }^{30}$ R. Xirau, op. cit., p. 25.

${ }^{31}$ Ibid., p. 29.

${ }^{32}$ J. Gorostiza, "La poesía actual de México. Torres Bodet: Cripta", en Poesía y prosa, p. 303. 
la fragancia sin nombre

de la piel.

Todo lo que el deseo

unta en mis labios:

la dulzura soñada

de un contacto,

el sabido sabor

de la saliva.

Y todo lo que el sueño

hace palpable:

la boca de una herida,

la forma de una entraña,

la fiebre de una mano

que se atreve.

¡Todo!

circula en cada rama

del árbol de mis venas,

acaricia mis muslos,

inunda mis oídos,

vive en mis ojos muertos,

muere en mis labios duros. ${ }^{33}$

Villaurrutia descubrió otra vida tras del sueño de la forma, descubrió la vida de la muerte, tras ese despeñadero en la nada de la poesía; tras ese descenso continuo e imparable del yo, en que las cosas pierden su certeza, se cumple esa exigencia de vivir todo desde esta muerte viva: muerte viva de la forma, muerte viva de la sustancialidad, muerte viva de lo definido, donde todo lo vivo cuando está vivo es signo de la muerte y del no ser, verdadera y vital razón de ser. La poesía de Villaurrutia logra una inversión difícil de aceptar y de consentir: pasar de vivir de acuerdo con la vida de horarios, deberes, ordenaciones, a otro modo de ser en el mundo donde el verdadero modo de ser no es la vida diurna, sino ese ámbito como el de la noche donde a través de nocturnos se nos hace entrar en otra legalidad, en la cual, cuanto más vivo, más oscilante, indefinido y equívoco es. La poesía mexicana alcanza una zona donde el ser ya no puede ser reducido a lo ente, una zona de oscilación donde todo adquiere

${ }^{33}$ X. Villaurrutia, op. cit., pp. 44-45. 
una existencia contradictoria. Tal es el ámbito de la diferencia ontológica donde el ser nunca es un ente. Leemos en "North Carolina blues":

\section{Confundidos \\ cuerpos y labios, yo no me atrevería \\ a decir en la sombra: \\ Esta boca es la mía. ${ }^{34}$}

Por eso, algo, si vive, "vive con mis ojos muertos"; ojos muertos, porque en ellos, ya no hay forma; algo vive, se agita y deviene, cuando abandonamos el sueño de la forma, cuando acontece el desdibujamiento del ente, cuando nos arrancamos de las cuencas los ojos. La muerte vive sólo con ojos muertos. Gorostiza cae en mientes de este hecho:

ay, ciegos de su lustre,

ay, ciegos de su ojo,

que el ojo mismo,

como un siniestro pájaro de humo,

en su aterida combustión se arranca. ${ }^{35}$

La forma, el engaño mayor, proviene de la luz, del día, del apego al ente, mientras que el sueño, la noche, en el contexto de Villaurrutia, es el momento en que ha desaparecido todo dominio sobre el ente y, por lo tanto, en la noche, la oscuridad es luz y, sueño, despertar: porque aquí no hay ni yo, ni mío, sólo ahí hay un dormido despierto. En "Nocturno miedo" muestra precisamente la experiencia de oscilación entre ser y no ser propia del dormido despierto:

Entonces, con el paso de un dormido despierto, sin rumbo y sin objeto nos echamos a andar.

La noche vierte sobre nosotros su misterio, $\mathrm{y}$ algo nos dice que morir es despertar.

¿Y quién entre las sombras de una calle desierta, en el muro, lívido espejo de soledad, no se ha visto pasar o venir a su encuentro y no ha sentido miedo, angustia, duda mortal?

${ }^{34}$ Ibid., p. 66.

${ }^{35}$ Arturo Cantú, En la red de cristal. Edición y estudio de "Muerte sin fin" de José Gorostiza. México, Casa Juan Pablos/UAm, 2005, p. 50. 
El miedo de no ser sino un cuerpo vacío

que alguien, yo mismo o cualquier otro, puede ocupar, y la angustia de verse fuera de sí, viviendo, y la duda de ser o no ser realidad. ${ }^{36}$

En "Nocturno en que habla la muerte" es la muerte quien toma la palabra, quien piensa y nos posee. Nada es sin la muerte, ni la tierra ni el sueño, pues dice la muerte "yo misma lo dibujo y lo borro". La muerte es el fundamento y lo que en realidad vivimos es un olvido de la muerte. Y abrir los ojos es justamente tener nada ante los ojos, la muerte es, como en "Nocturno miedo", abrir los ojos, despertar, por lo cual afirma Villaurrutia en voz de la muerte:

\section{[...] "Aquí estoy.}

Te he seguido como la sombra

que no es posible dejar así nomás en casa;

como un poco de aire cálido e invisible

mezclado al aire duro y frío que respiras;

como el recuerdo de lo que más quieres;

como el olvido, sí, como el olvido

que has dejado caer sobre las cosas

que no quisieras recordar ahora.

Y es inútil que vuelvas la cabeza en mi busca:

estoy tan cerca que no puedes verme,

estoy fuera de ti y a un tiempo dentro.

Nada es el mar que como un dios quisiste

poner entre los dos;

nada es la tierra que los hombres miden

y por la que matan y mueren;

ni el sueño en que quisieras creer que vives

sin mí, cuando yo misma lo dibujo y lo borro;

ni los días que cuentas

una vez y otra vez a todas horas,

ni las horas que matas con orgullo

sin pensar que renacen fuera de ti.

Nada son estas cosas ni los innumerables

lazos que me tendiste,

ni las infantiles argucias con que has querido dejarme

engañada, olvidada.

Aquí estoy, ¿no me sientes?

${ }^{36}$ X. Villaurrutia, op. cit., pp. 45-46. 


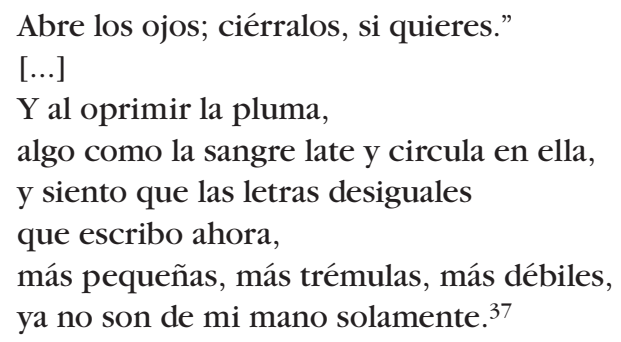

La muerte cuando toma la voz, sólo posible para la poesía, nos recuerda toda la serie de ilusiones con las que vivimos sin ella, cada uno de nuestros actos no nacen de un yo, ni de nuestros designios e intenciones, ni de nuestros proyectos ni esperanzas, nosotros y lo que llamamos yo, somos puestos por la finitud y el vacío. El verdadero ser en el mundo despierta de la ilusión del yo, a la realidad precursora y amo verdadero: la muerte, potencia verdaderamente hacedora, voluntad última. En Villaurrutia, como en Gorostiza, MORIR = DESPERTAR. Sin embargo, Gorostiza estaba necesitado de una afirmación más radical, de una afirmación en que despertar no fuera sólo el momento de la duda, de la incertidumbre sobre las cosas y sobre el yo, el momento de la instauración de las sombras, descenso al IN-FUNDAMENTO de la muerte, "anclar otra vez en la nada" 38 sino que fuera, además, el momento en que, con todo y a pesar de todo, podamos decir, como sucede al final de Muerte sin fin: “iAnda, putilla del rubor helado,/ anda, vámonos al diablo!" 39 Pero el poeta no es un ser con opciones, alguien que pueda decidir otro rumbo distinto al propio acontecimiento poético que lo toma.

\section{Los rigores de la nada: Gorostiza}

La conciencia no busca macerarse en líquidas determinaciones, sino endurecerse cada vez más.

Soren Kierkegaard

Para algunos críticos literarios, someter Muerte sin fin a una lectura filosófica, es decir, a una lectura consciente de la historia de la metafísica y de los problemas filosóficos, es un abuso. Dice Andrew Debicki: "no es difícil de notar

${ }^{37}$ Ibid., pp. 54-55.

${ }^{38}$ Ibid., p. 70.

39 Octavio Paz escribe en el Laberinto de la soledad: "Frente a la muerte hay dos actitudes: una, hacia adelante, que la concibe como creación; otra, de regreso, que se 
que Muerte sin fin es ante todo un poema, [...] que intenta comunicarnos experiencias y significados vitales concretos. Los eruditos que ignoraron este hecho, acabaron por pedirle algo que Gorostiza nunca quiso ofrecernos: un sistema lógico, o la defensa de una doctrina particular". ${ }^{40}$ Andrew Debicki no pudo comprender que pensar la filosofía como un sistema lógico o la defensa de una doctrina en particular resulta del todo anacrónico. La filosofía que se acerca a la poesía, a determinada poesía, busca romper la estrechez de los conceptos, de los sistemas y de cualquier ordenamiento racional, pues es en esa determinada poesía, precursora del pensar, donde se han decidido ya los caminos del pensamiento, porque esa determinada poesía apunta a la apertura amplia e indeterminada donde el pensamiento puede desplegarse. Por otro lado, una lectura de Muerte sin fin que a ultranza declara que el poema no puede leerse como filosofía, le impide darse cuenta hasta qué punto su lectura es también filosófica. ${ }^{41}$ Esa lectura no filosófica conduce a soslayar que el problema que subyace en el poema es la pregunta por el ser en cuanto tal, pregunta que no se detiene en este o en aquel ente, y que la libertad poética, en el caso de Gorostiza, consiste en alcanzar precisamente un horizonte cuya amplitud es irreductible a cualquier ente, como por ejemplo, a experiencias o vivencias humanas. Más bien, dichas experiencias y vivencias son fracturadas por la pregunta por el ser en cuanto tal, por toda su amplitud e indeterminación. El poema de la muerte, como acontece con Villaurrutia y Gorostiza, no enclaustra: abre, tiende a abrir y romper. En cambio, cuando se olvida la pregunta por el ser, se puede dar lugar a una lectura antropocéntrica como la de Debicki, lo cual se deja ver en afirmaciones como la siguiente: "el agua posee varios atributos humanos: es una muerte personificada, tiene una garganta, tiene sed [...] nos recuerda, de manera indirecta y no demasiado abstracta, que el líquido representa la materia humana”. ${ }^{42}$ La lectura que aquí propongo ancla conscientemente y sin ambigüedad el problema de la obra en la pregunta por el ser, el cual Heidegger pensó como el verdadero y único problema de la metafísica.

expresa como fascinación ante la nada o como nostalgia del limbo. Ningún poeta mexicano o hispanoamericano, con la excepción, acaso, de César Vallejo, se aproxima a la primera de estas dos concepciones. En cambio, dos poetas mexicanos, José Gorostiza y Xavier Villaurrutia, encarnan la segunda de estas dos direcciones" (O. Paz, Laberinto de la soledad. México, FCE, 2000, p. 67).

${ }^{40}$ Andrew Debicki, La poesía de José Gorostiza. México, Ediciones de Andrea, 1962.

${ }^{41}$ Como cuando afirma el propio Debicki: "La cualidad informe del agua y su mutabilidad (cambia de nube a mar) reflejan la confusión y falta de propósito del hombre, y también los cambios a los que está expuesto" (ibid., p. 68).

${ }^{42}$ Ibid., p. 69. 
Ahora, es indispensable aclarar el horizonte sustancialista de la metafísica occidental, si es que nosotros queremos comprender en qué medida Gorostiza lo desplaza. Para Aristóteles, la metafísica piensa aquello de lo que dependen todos los demás atributos y modos, es decir, la sustancia. Esto es, la metafísica piensa aquello de lo que dependen tiempo, lugar, cambio, relación, etcétera, "pues ninguno de ellos tiene naturalmente existencia propia ni puede separarse de la sustancia, sino que más bien, en todo caso, serán entes lo que anda y lo que está sentado y lo que está sano". El ente en cuanto tal es pues la sustancia, tanto en el orden del tiempo como en el orden del conocimiento, ya que "de los demás categoremas, ninguno es separable, sino ella sola". ${ }^{43}$ Pero hay algo más: en Aristóteles aquello que es y es sustrato de todas las transformaciones no es la materia sino aquello que se enuncia como forma (eidos), la cual mienta y engloba la esencia de cada cosa: su sustancia. La mesa mienta la esencia, es decir, superficie lisa, así como hombre mienta la esencia de éste, es decir, animal racional, porque especie o forma es lo que algo es primordialmente, mientras que la cantidad o la cualidad, es secundariamente. En Aristóteles, la referencia del ente, en cuanto que forma, a la alétheia o desocultamiento, ha desaparecido, desapareciendo así la relación de la presencia con la ausencia, de lo desoculto con lo oculto, como según Heidegger aconteció en el pensar originario de los griegos. Pues bien, cuando Gorostiza en Declaración de fe poética piensa que el "hombre está perdido en un abismo de luz", quiere decir que el hombre está perdido en las formas. Por ello, Arturo Cantú considera acertadamente que Muerte sin fin "trata de la naturaleza y vicisitudes de la forma". ${ }^{44}$ Este intérprete ha comprendido que el poema sólo puede leerse entendiendo el horizonte de la forma, ámbito donde nuestra conciencia y la historia de la metafísica se encuentran atrapadas. La conciencia está sostenida en el supuesto de la forma: "la forma en sí representa la legalidad de lo inteligible, y una materia conformada por la forma en sí significaría la posibilidad de un mundo habitable por el hombre". ${ }^{45}$ La forma es el horizonte vital de nuestra existencia, la forma es el riel en el que ha transcurrido nuestra humana existencia hasta ahora, hasta que la palabra poética lo desmiente. Como a Villaurrutia, a Gorostiza le interesa romper el confinamiento horizóntico de la forma. ${ }^{46}$ Por eso el poema arranca de esa terrible evidencia destinal:

${ }^{43}$ Aristóteles, Metafísica. Madrid, Gredos, 1998, 1028b.

${ }^{44}$ A. Cantú, op. cit., p. 227.

${ }^{45}$ Ibid., p. 282.

${ }^{46}$ Es un error pensar que en Muerte sin fin "toda la reflexión está basada [...] en la relación entre forma y sustancia”, porque vistas las cosas desde la perspectiva de Aristóteles, la forma es sustancia, la forma mienta la sustancia; lo correcto es decir que el poema trata sobre las relaciones entre la forma y la no forma, la forma y lo infor- 
Lleno de mí, sitiado en mi epidermis por un dios inasible que me ahoga, mentido acaso

por su radiante atmósfera de luces que oculta mi conciencia derramada, mis alas rotas en esquirlas de aire, mi torpe andar a tientas sobre el lodo; lleno de mí -ahíto- me descubro en la imagen atónita del agua,

[...] que nada tiene sino la cara en blanco ${ }^{47}$

Como buen lector de Schopenhauer, le interesa ver a través del velo del maya o del mundo como representación el modo de ser de la nada, de manera que ya no pueda decir como Aristóteles: "lo que cambia es necesariamente un ente". ${ }^{48}$ Para él, apariencias son todo cuanto ostenta la forma, meras "máscaras de espejos" como leemos en el poema sexto:

En el nítido rostro sin facciones

el agua, poseída,

siente cuajar la máscara de espejos

que el dibujo del vaso le procura. ${ }^{49}$

Nosotros hablábamos de que la poesía alcanza cierta amplitud, rompe un confinamiento horizóntico; pues bien, la poesía de Gorostiza primero ha de descubrir en qué consiste dicho confinamiento. Para Gorostiza, nuestra conciencia está atrapada en la ilusión de la forma, en el apego a la forma; es

me. Para Aristóteles, "esencia es la sustancia de cada cosa" (1031a), es decir, sólo hay esencia de especies de un género, ahora la especie es "la forma que se manifiesta en lo sensible" (1033b), la figura visible, y ésta es su quididad, esto es, "lo que se dice que es en cuanto tal" (1029a), lo que se expresa en la definición: esfera, mesa, etc. Ahora podemos entender lo dicho por Aristóteles: "el ser separable y algo determinado parece corresponder sobre todo a la sustancia; y por eso la especie y el compuesto de ambas [forma y materia] parecen ser sustancia en mayor grado que la materia" (1029a). Por lo tanto, sustancia es forma.

${ }^{47}$ A. Cantú, op. cit., p. 21.

${ }^{48}$ Aristóteles, Metafísica, 1010a.

${ }^{49}$ A. Cantú, op. cit., p. 37. En esta lectura no se intenta un recorrido parte por parte del poema, se asume la visión del conjunto y las repeticiones del autor en distintos poemas. Por ejemplo, la idea de la forma encerrada en el vaso, que oculta en realidad su rostro sin facciones, se repite en el poema sexto. 
en ese apego que el hombre se ha perdido, porque es incapaz de ver que ha tomado el vaso, la forma por esencia y no el agua que contiene, agua que "nada tiene sino la cara en blanco", es decir, ha olvidado lo in-forme. Para Gorostiza, más allá de la forma está lo informe. Para él, es indispensable ver a través de la forma la vida muriéndose. Sólo saliendo del sueño de la forma es posible el acontecimiento originario de la no forma. ${ }^{50}$ Muerte sin fin atraviesa en su itinerario la ilusión de la forma y en ese recorrido hará un cuestionamiento de todos los ejes en los cuales se sostenía la existencia. El hombre está perdido en la idea del orden del universo, en la idea de la sustancia divina, la idea de la razón, en suma, en la idea de tener y poseer algo al fin y, a la vez, un lugar donde establecerse. El edificio de la razón, esa "sed de hielo justo", forma parte del sueño de la forma representada por el agua estrangulada en el vaso o "en su orbe tornasol soñando" como se lee en un fragmento del poema primero:

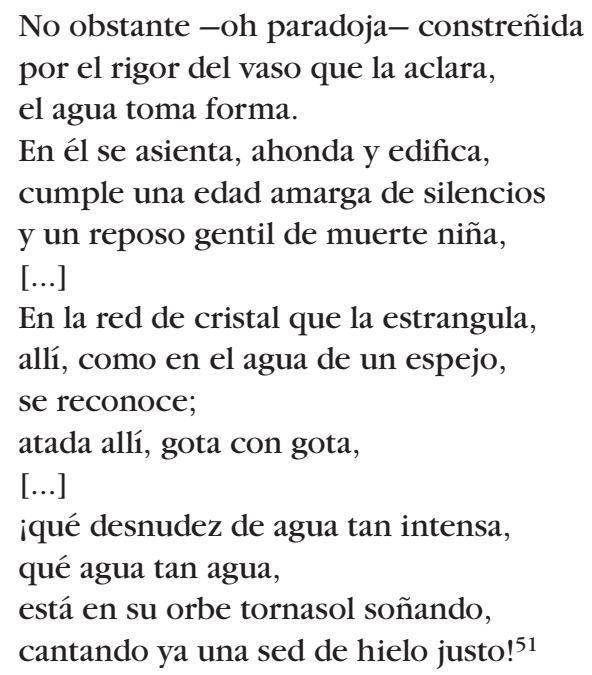

Desde el primer poema, el aparente tono celebratorio de la forma es más bien ironía; el poeta introduce el tono fundacional de la forma, para después desmoronarla. Ironía y tragedia se conjugan en el poema. Gorostiza pone la

${ }^{50} \mathrm{El} 18$ de diciembre de 1939 Jorge Cuesta publica una reseña sobre Muerte sin fin, en ella afirma: "estos desposorios del agua con el vaso, el objeto del amor no es la forma, sino de la disolución de la forma en el consumo de la materia; el objeto del amor [...] ya no está en lo que los ojos aprehenden" (Jorge Cuesta, "Primeras reseñas de muerte sin fin", en J. Gorostiza, Poesía y poética, p. 341).

${ }^{51}$ A. Cantú, op. cit., pp. 21-22. 
forma y la quita incansablemente, porque en eso consiste la tragedia humana, en hacernos creer la vida algo, a todas luces insostenible, para inmediatamente desilusionarnos.

¡agua fofa, mordiente, que se tira,

ay, incapaz de cohesión al suelo!

[...]

y en cualquier escenario irrelevante

-en el terco repaso de la acera,

en el bar, entre dos amargas copas

o en las cumbres peladas del insomnio- 52

La poesía de Gorostiza, antiaristotélica como es, hace del ser un accidente, advierte en el cortejo del ser, el derrumbe de la forma y, con ello, el de la sustancia; esta vulneración da lugar a la poesía. Contrario al movimiento aristotélico y cartesiano en pos de la independencia de la sustancia, la poesía gorostiziana conduce a la desustancialización del ente, mostrando más bien la dependencia y no separación de la sustancia de la no forma y de la nada. Gorostiza no se detiene en ninguna sustancia, el movimiento poético lo conduce más allá de la sustancia y, en ese sentido, realiza el paso más allá de la metafísica, hacia la nada, para volverla el verdadero escenario del ser. Es decir, al chocar la muerte con la palabra del poeta éste no advierte "algo separable y determinado", no advierte formas ni esencias, advierte más bien lo informe. Mordecai S. Rubín nos dice que el agua "que simboliza la sustancia sin forma, no es más que informidad pura e insistente". ${ }^{53}$ El agua no tiene forma por mucho que aparezca en la forma específica de la nube o del río. De acuerdo con esta lectura ontológica, en la médula y estructura del ser está la nada, la existencia desnuda de la forma. Inserto en medio del movimiento de despedida del ser entendido como ente, el poeta alcanza "en el vértice" a mirar el ente como mera apariencia y juzgarlo verdaderamente así. Eugenio Florit escribe: "El poema de Gorostiza [...] nos deja [...] tristes de ver la infinita muerte de la materia y la desvalida orfandad de la forma". ${ }^{54}$

Mordecai S. Rubín señala la cercanía del poeta con el pensamiento oriental, para el cual la idea del sujeto y el objeto son una ilusión. Es plausible pensar que por intermediación del libro de Schopenhauer, El mundo como voluntad y representación, el cual Gorostiza leyó, el poeta profundizó en la idea de la

52 Ibid., p. 24.

53 Mordecai S. Rubín, Una poética moderna. Muerte sin fin de José Gorostiza. México, UNAM, 1966, p. 32.

${ }^{54}$ Eugenio Florit, "Palabras iniciales", en ibid., p. 11. 
ilusión de la forma, que según el propio Schopenhauer es idea corriente en la India en general a través de la filosofía Vedanta y el budismo. Al final de su monumental obra, Schopenhauer afirma: "este mundo nuestro tan real, con todos sus soles y galaxias, no es nada”. Después de esta afirmación, Schopenhauer inserta una nota que dice: "Esto es también el Prajnaparamita (la otra ribera) de los budistas, el 'más allá de todo conocimiento', esto es, del punto donde sujeto y objeto dejan de ser tales". Es decir, Prajnaparamita es el supremo conocimiento que va más allá de la conciencia, del pensamiento, del sentimiento, del albedrío, pues desde la sabiduría (Prajna) no existe nada a lo cual la mente pueda aferrarse. Precisamente es en el Prajnaparamita hdraya o El Sutra del corazón, texto atribuido a Avalokiteshvara, donde se encuentra el dictum budista: "la forma es vacío y el vacío es forma, no existe otra forma que la vacuidad ni otra vacuidad que la forma”, afirmación que se encuentra muy en consonancia con el pensamiento de Gorostiza. ${ }^{55}$ Es decir, ¿no es así cuando vemos marchitarse la rosa? ¿La rosa en su deshacerse? ¿El atardecer cambiante en la multiplicad de formas? ¿El lago deshaciéndose en círculos? Rosa, lago y atardecer, ¿no son acaso forma en la no forma?

La razón occidental no ha querido ver que todo descansa en el marco de fondo de la nada, no ha querido saber que la forma no se cumple-como dice Gorostiza en el poema octavo-, no se cumple porque las formas sangran. Gorostiza apunta no a algo preciso y definido, encerrado en sí mismo, sustentado finalmente en un Dios, sino lo que la razón y la idea Dios ocultan: la no forma, la forma derramada como el agua. Desde el inicio del poema Muerte sin fin, Gorostiza atestigua la fragmentación y desustancialización de todas las cosas como el sustento mismo de todas las cosas y, por el cual, como el agua y siendo de agua, la forma es frágil, mera ilusión.

\footnotetext{
¡Más qué vaso -también- más providente!

Tal vez esta oquedad que nos estrecha

en islas de monólogos sin eco,

aunque se llama Dios,

no sea sino un vaso

que nos amolda el alma perdidiza, ${ }^{56}$
}

${ }^{5}$ El sutra del corazón. Barcelona, Kairós, 2001, p. 76. Mónica Mansour en "El diablo y la poesía contra el tiempo" confirma que Gorostiza "se interesa más en autores y textos más antiguos -los griegos, la Biblia, Buda, Popol-Vuh, el Zohar, Khavyam y las obras de Dante- o más modernos: Donne, Blake, Browning, Goethe, poesía inglesa y poesía narrativa francesa de este siglo, así como poesía mexicana contemporánea" (Mónica Mansour, "El diablo y la poesía contra el tiempo", en J. Gorostiza, Poesía y poética, p. 222).

${ }^{56}$ A. Cantú, op. cit., p. 23. 
Desde la conciencia de la no forma, Gorostiza apunta a la muerte de Dios. La índole de Dios no difiere de la nuestra: pura forma. Después del sueño/ ilusión de la forma representada por el agua contenida por un vaso, comienza a desmoronarse ese sueño, en el tercer poema; en ese lugar se muestra ahora el sueño de la razón, que "distribuye los mundos en el caos, los echa a andar como autómatas" y "saca de ellos cintas de sorpresas", sistemas que nos elevan hasta el cielo, para luego estar destinados a desbaratarse, para convertirse cada uno de ellos en un "frondoso discurso de ancha copa", en meras "miradas de atropina". Al mismo tiempo, en ese mismo poema se elabora una contrastación entre los sueños y lo que dichos sueños, "miradas de atropina", no quieren ver: el "rencor de la molécula" y "el tumor, la úlcera y el chancro".

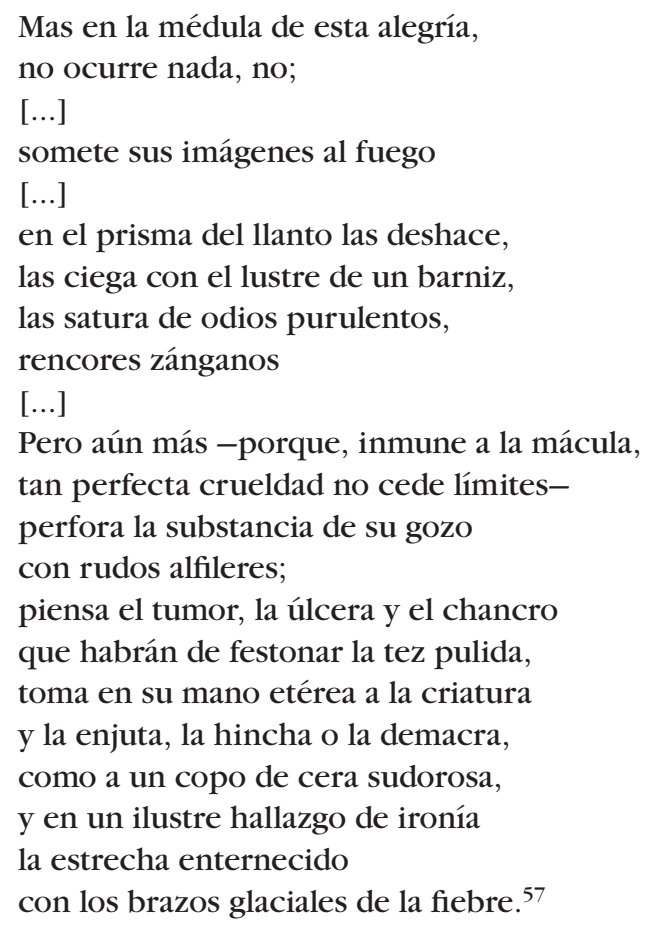

Por si se tenía alguna duda, tras la muerte de un Dios creador del orden del universo, lo que se encuentra es lo que nos rehusamos a ver: la pérdida imparable de la forma, la destrucción inevitable y, como lo afirma Debicki, ahora sí, acertadamente: "el esfuerzo de la inteligencia de encontrar un poder

${ }^{57}$ Ibid., pp. 27-29. 
formador se ha tornado un sueño impotente" ${ }^{58}$ Es decir, en el poema tercero, Gorostiza, ya abierto el mismo horizonte de la nada, descubre lo informe en marcha, el "sueño desorbitado", dinámico, procesual, imparable, sin cesar, sin fin, de la muerte:

Pero el ritmo es su norma, el solo paso, la sola marcha en círculo, sin ojos; así, aun de su cansancio, extrae

¡hop!

largas cintas de cintas de sorpresas

que en un constante perecer enérgico, en un morir absorto, arrasan sin cesar su bella fábrica hasta que -hijo de su misma muerte, gestado en la aridez de sus escombrossiente que su fatiga se fatiga,

$[\ldots]$

y sueña que su sueño se repite, irresponsable, eterno, muerte sin fin de una obstinada muerte, sueño de garza anochecido a plomo que cambia sí de pie, mas no de sueño, que cambia sí la imagen, mas no la doncellez de su osadía ${ }^{59}$

De este modo, el circularismo de la muerte-vida-muerte es la esencia del universo, no la teleología ni la redención. ${ }^{60}$ Tenemos, pues, que a la ausencia de la forma, le sigue la idea de la impermanencia de la impermanencia encerrada en aquel circularismo y, por lo tanto, la ausencia de finalidad del devenir. Por eso, Gorostiza en este poema tercero, comienza a cuestionarse el sentido de la inteligencia o de la razón en medio del continuo holocausto del ente, al afirmar: "ioh inteligencia, soledad en llamas", como lo hará, por segunda ocasión, en el cuarto poema. Y es que la razón es incapaz de

${ }^{58}$ A. Debicki, op. cit., p. 78.

${ }^{59}$ A. Cantú, op. cit., pp. 29-30.

60 "Gorostiza rechaza la teleología; el circularismo es mecánico. Ha indicado ya algo de eso ya con 'planta semilla planta', pero ahora lo amplifica con la idea de la desintegración, la muerte continua que es una característica inseparable de todo ese movimiento y, por lo tanto, es una definición de marcha en círculo: morir nacer y empezar a morir otra vez" (Cf. M. S. Rubín, op. cit., p. 65). 
probar en el rencor de la molécula

[...]

y el gusto de su fruta prohibida,

ay, sin hollar, semilla casta,

sus propios impasibles tegumentos. ${ }^{61}$

La conciencia poética descubre esos sueños de la razón que se ahogan en un vaso de agua, en conceptos, en redes de cristal, y que olvida, "pobrecilla del agua, que no tiene nada" (quinto poema). El olvido ontológico es, pues, el olvido de la nada entendida como muerte imparable y sin fin; la metafísica ha olvidado el ser ahíto de nada, como el agua, que no sabe a nada y no tiene nada. La nihilidad es la norma del ser ("pero el ritmo es su norma") y alcanza a la razón misma. Gorostiza concibe en el poema cuarto incluso la nihilidad de la razón, es decir, piensa la nihilidad de la inteligencia con todo y su lenguaje. ${ }^{62}$ La razón no puede probar el gusto de su fruta prohibida: comprender. En Muerte sin fin, "la inteligencia - dice Mordecai S. Rubín- es capaz de concebir su propia negación, su no finalidad". ${ }^{63}$ La impermanencia y la nihilidad del ser atraviesan la razón: se cumplen hasta la negación misma de la razón. Y es que el trabajo abstracto de la razón, que sólo absorbe esencias, la hace quedar enamorada de sí, es decir, queda enamorada de sus edificios conceptuales que embellecen todo y "lo encumbra más allá de las alas", permaneciendo entonces el sueño de la razón recreándose en sí mismo y, a la vez, concibiendo las sustancias, encerradas en sí mismas. Por lo mismo, para Gorostiza, la inteligencia en su temor de la materia, no es más que "angélico egoísmo que se escapa / como un grito de júbilo sobre la muerte”. El resultado de esta huida de la carne es un juego de espejos, una razón ensimismada, una razón inmersa en sus conceptos, espejismos e ilusiones o en un "hermético sistema de eslabones". La razón es creadora de "rosas pétreas", sin pulso y sin tiempo, razón estéril que en su abstinencia angustiosa, como se lee en el mismo cuarto poema, "escucha ya en la estepa de sus tímpanos / retumbar el gemido del lenguaje / y no lo emite". La razón es sorda, incapaz de emitir gemido, porque está atenida a las esencias, a lo imperecedero, a las sustancias y sólo así mantiene su unidad, su identidad posible. Sólo así queda consigo misma en llamas: olvidando "la sorda pesadumbre de la carne", sin admitir: "el escarnio brutal de esa discordia, que nutren vida y muerte inconciliables, acampadas en la célula”.

${ }^{61}$ A. Cantú, op. cit., p. 30.

${ }^{62}$ Arturo Cantú considera que en este poema cuarto la inteligencia de la que habla Gorostiza es la inteligencia divina, sin embargo, considero que es una reflexión sobre la razón filosófica (Cf. A. Cantú, op. cit., p. 277).

${ }^{63}$ M. S. Rubín, op. cit., p. 69. 
La razón está incapacitada de ver y escuchar fuera de sus conceptos "una nada más, estéril, agria, [...] que reconcentra su silencio blanco / en la orilla letal de la palabra”. Por eso, el aleluya que cierra el cuarto poema es el aleluya liberador. Tras desaparecer al fin la razón creadora de la sustancia, del sentido y de la permanencia, puede emerger una razón austera, desposeída de los sueños y de las ilusiones. Es decir, al ir a ese empobrecimiento, a "ese silencio blanco reconcentrado / en la orilla de la palabra y en la inminencia misma de la sangre" que aparece tras la visión de la muerte sin fin, tiene algo que desde el primer poema es manifiesto: el agua "que nada tiene / sino la cara en blanco", tema del poema quinto, al cual regresaremos más tarde. Es decir, el aleluya de Muerte sin fin, es la alegría por haber despertado del sueño de la forma, el gozo por haber visto al fin la diferencia ontológica entre el ser y el ente, o el haber despertado a esa diferencia en virtud de la "nada que reconcentra su silencio blanco". Gorostiza como Villaurrutia siempre buscó el espacio de la disolución del ente, ahíto de nada y de silencio.

La atracción de Gorostiza por la confluencia entre vida y muerte estaba ya en el poemario Canciones para cantar en las barcas. En "La orilla del mar", gracias a su sencillez o simplicidad, el poema brinda apoyo ontológico a la esencial interpenetración entre ser y nada. "No es agua ni arena/ la orilla del mar.// Las cosas discretas,/ amables, sencillas;/ las cosas se juntan/ como las orillas.// Lo mismo los labios,/ si quieren besar./ No es agua ni arena/ la orilla del mar". El pensamiento educado en el principio de identidad no ha podido ver la orilla ontológica, donde la vida y la muerte, el ser y el no ser, el yo y el tú se juntan o coinciden. El poema apunta a la interrelación y, por lo tanto, a la disolución de toda idea de forma encerrada en sí misma. Gorostiza no sólo registra la ruptura de la sustancia sino además el interminable fluir de las cosas o el interminable dejar de ser. La actitud cuestionante hacia la forma y la sustancia, es también atención al espacio no decidido entre el ser y la nada. En el primer poema de "Presencia y fuga" del Poema frustrado leemos: "En el espacio insomne que separa/ el fruto de la flor [...] / una muerte de agujas me acapara". Gorostiza apunta al espacio no decidido entre el ser y la nada, a la zona de la desustancialización. Las cosas son en el acontecimiento eterno de desdibujarse a sí mismas, al juntarse e interpenetrarse. El desdibujamiento, la pérdida del límite y de contornos, es una obsesión para Gorostiza también en Muerte sin fin:

Pero el vaso en sí mismo no se cumple.

Imagen de una deserción nefasta

[...]

articula el guión de su deseo;

se ablanda, se adelgaza; 
ya su sobrio dibujo se le nubla, ya, embozado en el giro de un reflejo, en un llanto de luces se liquida. ${ }^{64}$

Es decir, Gorostiza atestigua el terrible engaño del sueño de la forma, su modo de ser instantáneo y fugaz, pues "presume la materia/ que apenas cuaja su dibujo estricto/ y ya es un jardín de huellas fósiles" (octavo poema). La vida y la muerte, por lo tanto, en la poesía de Gorostiza rompen su ancestral confinamiento o su encierro en uno o en otro. Por lo mismo, cuando Gorostiza afirma: "Quiero decir que la muerte para mí es lo mismo que la vida, es el reverso, la otra cara de la medalla", apunta a una conciencia ontológica distinta al pensamiento occidental, es decir, apunta a una experiencia del ser en donde la nada está en comunión y no en oposición o en contradicción con el ser. Para esta lectura de Muerte sin fin, Gorostiza realiza una conciencia ontológica distinta. El gran horizonte de la metafísica occidental verdaderamente se abandona cuando se cuestiona la sustancia, es decir, cualquier sustancia, incluida la sustancia divina, pues desde siempre la sustancia ha sido pensada como aquello irreductible que no puede dejar de ser o por aquello que es por sí mismo y tiene su fundamento en sí mismo; por el contrario, la sustancia-forma tiene un fundamento más amplio, está contenida en la nada, queda absorbida por la nada, se da en dependencia con la nada. Gorostiza se introduce en los entresijos de la conciencia filosófica. Sólo otro modo de pensar puede captar la realidad de la descomposición; sólo una razón que ha decidido salir del hermetismo de los conceptos y constatar que tras la forma está la muerte, la realidad de su descomposición y su desfiguración, esto es, que tras la forma está la no forma, puede trascender la soledad en llamas de la inteligencia, porque "el aspecto de la vida y el de la muerte son igualmente reales -dice Keiji Nishitani-, y la realidad es aquello que aparece ahora como vida ahora como muerte. Es ambas, la vida y la muerte y, al mismo tiempo, no es ni la vida ni la muerte". ${ }^{65}$

Desfondar el campo de la sustancia (forma) es desfondar el campo de Dios y de la conciencia al mismo tiempo, para dar lugar con el único asiento sin fondo donde no hay dominio ni encierro en las redes de cristal de la conciencia o distribución de los mundos en el caos, sino desdibujamiento de todos los ejes; a ese desdibujamiento lo llamo "el horizonte de la nada". Al sauce "no le queda sino el tronco prieto,/ desnudo de oración ante su estrella" (poema noveno). Hacia el sexto poema de Muerte sin fin, la forma no es más que

${ }^{64}$ A. Cantú, op. cit., pp. 38-39.

${ }^{65}$ Keiji Nishitani, La religión y la nada. Introd. de James W. Heisig y trad. de Raquel Bouso García. Madrid, Siruela, 1999, p. 91. 
"idolatría, sí, idolatría" como la religión que "no le basta ser un puro salmo", como "estas limpias metáforas cruzadas" de la poesía, o como este "estar de pie frente a las cosas" y tomarlas como objetos. E insistirá todavía Gorostiza en el poema séptimo: "Pero el vaso (forma) en sí mismo no se cumple" y se vuelve a machacar una vez más esta sentencia al afirmar al inicio del poema octavo: "Mas la forma en sí misma no se cumple". Es decir, la forma no se cumple ni a nivel estético ni a nivel ontológico por más que ella esté segura de su "orondo imperio", pues "apenas cuaja su dibujo estricto/ y ya es un jardín de huellas fósiles" y "La rosa edad que esmalta su epidermis/ - senil recién nacida-/ envejece por dentro a grandes siglos". El generalizado darse del colapso hacia el poema nueve alcanza, incluso al lenguaje, momento fundamental:

sí, todo él, lenguaje audaz del hombre,

se le ahoga -confuso- en la garganta

y de su gracia original no queda

sino el horror de un pozo desecado

que sostiene su mueca de agonía. ${ }^{66}$

Cuando se pierde el lenguaje, asunto al que regresaremos más adelante, se encuentra, entonces, a lo único real más allá de la forma: el escenario de la nada, que aparece en el noveno poema. Dice Gorostiza:

perpetuo instante del quebranto, cuando la forma en sí, la pura forma, se abandona al designio de la muerte y se deja arrastrar, nubes arriba, por ese atormentado remolino en que los seres todos se repliegan hacia el sopor primero, a construir el escenario de la nada. ${ }^{67}$

Para Debicki, mediante versos cortos Gorostiza nos hace sentir "la aceleración del anonadamiento", "el futuro de la materia: es el de convertirse en vacío completo". ${ }^{68}$ Las resonancias schopenhauerianas del poema son evidentes; en la naturaleza tal y como es concebida por Schopenhauer vemos el conflicto, la lucha y alternancia en la victoria. Dice Shopenhauer: "para vivir la voluntad se consume sin excepción a sí misma y es su propio alimento bajo

\footnotetext{
${ }^{66}$ A. Cantú, op. cit., p. 46.

${ }^{67}$ Ibid., pp. 43-44.

${ }^{68}$ A. Debicki, op. cit., p. 108.
} 
diferentes formas". ${ }^{69}$ Para Schopenhauer, como en Gorostiza, en la naturaleza reina la discordia.

sí, paso a paso, muerte a muerte, locos, se acogen a sus túmidas matrices, mientras unos a otros se devoran al animal, la planta a la planta, la piedra a la piedra, el fuego al fuego, el mar al mar, la nube a la nube, el sol. ${ }^{70}$

El escenario de la nada de Gorostiza, como la voluntad de Schopenhauer, se cumple autodestruyéndose a sí misma. Dice ahora Schopenhauer:

Así en la naturaleza vemos por doquier conflicto, lucha y alternancia en la victoria, reconociendo en todo ello ulteriormente y con mayor claridad la consustancial discordia de la voluntad consigo misma. Cada nivel de objetivación de la voluntad le disputa a los otros, la materia, el espacio y el tiempo. [...] Esta lucha universal alcanza la mayor visibilidad en el mundo animal, que tiene al mundo vegetal como alimento suyo y en donde a su vez cada animal se vuelve presa y alimento de algún otro, esto es, la materia en que se presenta su idea ha de retirarse de la escena para dar paso a otra idea, dado que cualquier animal sólo puede alcanzar su existencia mediante la continua eliminación de una existencia ajena; así que para vivir la voluntad se consume sin excepción a sí misma y es su propio alimento bajo diferentes formas. ${ }^{71}$

${ }^{69}$ Arthur Schopenhauer, El mundo como voluntad y representación. México, FCE, 2003, t. 1, pp. 237-238.

${ }^{70}$ A. Cantú, op. cit., pp. 50-51. Que Gorostiza conocía a Schopenhauer se trasluce en una de sus cartas dirigida a su hermano Celestino: "Lo peor es que no son sino anestésicos de la voluntad. Toda esa actividad de la que me hablas..." (J. Gorostiza, Epistolario..., p. 218). Es decir, Gorostiza de alguna manera en Europa, en ese momento vivía en París, había leído a Schopenhauer, uno de los primeros filósofos occidentales conocedores del budismo, quien en el Mundo como voluntad y representación afirma: "no puede haber satisfacción ni felicidad duraderas, sino siempre sólo alivio de un dolor o una carencia, al que ha de seguir de nuevo dolor o el aburrimiento o también una vana añoranza" (A. Schopenhauer, op. cit., p. 416) y añade en el párrafo siguiente: la voluntad [...] es una tendencia sin objetivo ni final alguno" (ibid., p. 417). A este apetito sin principio ni fin los budistas lo llaman tanha, es decir, anhelo o sed.

${ }^{71}$ Ibid., p. 239. 
Muerte sin fin da con el escenario de la nada que, como el dao, "trata a todas las cosas como perros de paja". Muerte sin fin nos lanza al horizonte de la nada sin ejes, ni referencias, ni privilegios, ni jerarquías, y, por lo tanto, a un modo de ser del ser absolutamente impersonal. ${ }^{72}$ Por esta razón, Octavio Paz piensa a este escenario de la nada como un "drama sin personajes". ${ }^{73}$ Alfonso Reyes capta lo absolutamente impersonal de Muerte sin fin:

El rocío se lleva consigo algo como los espectros de las corolas, y las corolas se beben otra vez el rocío. Retorno eterno. El espíritu se materializa [...] se va configurando una segunda naturaleza, tejida de interrogaciones [...] pero para merecer el premio definitivo, convertido ahora en algo como una estatua de cristal de roca [...] La vida se hace muerte sin fin. La sustancia, sutilizada, se asfixia y perece en eternidad de la forma. ${ }^{74}$

Al alcanzar a ver la gran conflagración, la pira del ser ("en la pira arrogante de la forma", poema noveno), el poeta se libera y nos libera del apego a la forma, de la sumisión al ente, al recordarnos que el día y la noche acampan en la célula, que la vida y la muerte están presentes a cada instante, que es a la nada donde todas las cosas regresan y que no hay dominio sobre el ser. Efectivamente, si como dice Octavio Paz la poesía es comunión con lo real, y lo real es entendido como muerte en la vida, vida en la muerte, Gorostiza

${ }^{72} \mathrm{El}$ dao (o incorrectamente tao) es el entramado de las transformaciones o el curso que se abre dentro de ese entramado. En el daó́smo nada es esto, sino un estado determinado del entramado yin yang sobre el cual no hay poder que obre y, por lo mismo, el sabio daoísta es quien sabe seguir el curso o tao, acomodarse a él, cultivarlo. Dice Chuang-tsé, pensador daoísta: "Sólo acomodándose a ese eje se puede penetrar en el círculo, para así corresponder a los infinitos cambios" (Zhuan zi, Maestro Chuang Tsé. Barcelona, Kairós, 2001, p. 46). En el Tao te king de Lao tsé leemos: "El cielo y la Tierra no muestran parcialidad/tratan a las cosas como perros de paja/El sabio no tiene parcialidad/trata al hombre como a perros de paja" (México, Premiá Editora, 1982, p. 31). Se sabe que los perros de paja en China eran unas pequeñas figurillas que después de vestirse y adornarse, eran pisoteadas y lanzadas al fuego (Cf. Lao zi, Tao te king. Madrid, Siruela, 2003, p. 38).

${ }^{73}$ O. Paz, El laberinto de la soledad, p. 69. Por otro lado, quiero insistir algo de la lectura de Andrew Debicki en su libro La poesía de Gorostiza aunque repetitiva, como otras lecturas por su afán de ser sistemáticas y seguir al pie de la letra el orden del poema, entiende que el hombre no es más que un "morfinómano" (p. 93). Gorostiza busca trascender el humano anhelo de la forma, yendo a la nada. Por lo tanto, es un error pensar como lo hace Debicki que "la obra trata de problemas humanos", Muerte sin fin busca llevarnos más allá del circuito de lo propio, busca desapropiarnos. (Cf. p. 96).

${ }^{74}$ Alfonso Reyes, "Contestación de Alfonso Reyes al discurso de José Gorostiza", en J. Gorostiza, Poesía y prosa, pp. 514-515. 
alcanza con mucho el terruño de todas las cosas, la apertura ontológica, la mismidad esencial, el ser al unísono con la nada, el ser en la nada y la nada en el ser. Por esta razón, este drama sin personajes, absolutamente impersonal, es en realidad nuestro más acá, está más acá de todas las cosas. La nada es el lugar de la desinteriorización, podemos decir, la nada es fuerza de despersonalización porque el escenario de la nada es el lugar de todas las cosas, no importa si es dios, hombre o animal o planta: a ella regresan. En el horizonte de la nada, tal y como es abierto por Gorostiza, acontece un retorno a la nada, leemos en el poema noveno

hasta que todo este fecundo río de enamorado semen que conjuga, inaccesible al tedio,

el suntuoso caudal de su apetito, no desemboca en sus entrañas mismas, en el acre silencio de sus fuentes, entre un fulgor de soles emboscados, en donde nada es ni nada está, donde el sueño no duele, donde nada ni nadie, nunca, está muriendo y solo ya, sobre las grandes aguas, flota el Espíritu de Dios que gime. ${ }^{75}$

Nos dice Ramón Xirau: "Toda cosa, en su muerte, participa de un furioso deshacer en una vuelta a sus orígenes, de lo vivo a la pre-vida, de la pre-vida a la piedra, de la piedra a la nada. Nos encontramos [...] sin centro del mundo, sin eje de creencia, sin cosmos que estructure el caos, sin regreso, vuelta a la nada" ${ }^{76}$ A este proceso de regreso hacia la nada, como regreso a los orígenes, se le ha llamado "descreación". Debicki afirma: "Esta espantosa conclusión aparece como una retrogresión, una evolución al reverso que hará del ser la nada". ${ }^{77}$ Arturo Cantú en En la red de cristal señala que en ese proceso de descreación "el Dios inexperto que soñó el sueño del mundo, desaparece también con la desaparición de todas las cosas", desaparecido lo creado, desaparece su creador. ${ }^{78}$ En este sentido, no hay que dejarse engañar con respecto a los epígrafes ${ }^{79}$ que abren Muerte sin fin que simplemente muestran los excesos

${ }^{75}$ A. Cantú, op. cit., p. 51.

${ }^{76}$ R. Xirau, op. cit., p. 18.

${ }_{77}$ A. Debicki, op. cit., p. 98.

${ }^{78}$ A. Cantú, op. cit., p. 226.

${ }^{79}$ Uno de ellos reza: "Conmigo está el consejo y el ser; yo soy la inteligencia; mía es 
de la tradición judeocristiana. El último de los epígrafes dice "Mas el que peca contra mí defrauda su alma; todos los que me aborrecen aman la muerte" (Proverbios 8, 36). Gorostiza pensará lo contrario: "un Dios que produce la muerte tiene que ser él mismo la muerte, la destrucción y los escombros", afirma Arturo Cantú. ${ }^{80}$ Este Dios que peca contra sí mismo ama la muerte. Gorostiza obliga a Dios a desdecirse y a morirse. Según Arturo Cantú, en el poema "la intención aparente de salvar de toda culpa a Dios", en realidad, hace "más grave su descuido e irresponsabilidad". ${ }^{81}$ Hacia el final de En la red de cristal Arturo Cantú, precisamente en su interpretación del noveno poema, considera que el fin del sueño de la forma conduce a la desaparición del mundo, a la desaparición de Dios y de la racionalidad:

El Dios que ha muerto es el nuestro, es el Dios que nos creó así sólo sea como imágenes dentro de un sueño instantáneo. El Dios que pervive, ajeno a los componentes, la estructura y el designio del sueño, jamás podrá ser conocido por nosotros que no podemos comprender sino lo vivido, y que vivimos por un mundo creado por un Dios muerto. La muerte de la forma en sí, que es otra cara de la muerte de Dios, es la muerte de la racionalidad [...] Sin Dios y sin forma en sí no puede haber legalidad inteligible. ${ }^{82}$

A estas alturas estamos en condiciones de tener un acercamiento a la nada desprejuiciado, es decir, formado hermenéuticamente y, por lo mismo, estamos muy lejos de pensar que "la nada no se puede ni decir ni pensar", como pensó Parménides, de manera categórica, instando a no tomar, de manera alguna, el camino del no ser, sino el camino del ser; este último, para él, el camino de la verdad. Sin embargo, acercándonos a ciertas producciones de pensamiento disidentes de la cultura occidental, como la mística y la literatura y, a otras culturas, como la budista y la taoísta, así como a la actual Escuela de Kyoto que en este texto ha aparecido a través de la voz de Nishitani Keiji, nos encontramos con que la nada no es lo absolutamente falto de rigor o un capricho, una ocurrencia, un desvarío, sino un camino de pensamiento destinado a poner fin a la ilusión de la existencia del mundo, de la existencia de Dios y de la existencia del yo, para hacer aparecer un horizonte sin preponderancias ajeno a designios metafísicos y racionales, un más allá de lo humano y de lo

la fortaleza (Proverbios: 8, 14). El segundo: "Con él estaba yo ordenándolo todo; y fui su delicia todos los días, teniendo solaz delante de él en todo tiempo (Proverbios: 8, 30).

\footnotetext{
${ }^{80}$ A. Cantú, op. cit., p. 275.

${ }^{81}$ Idem.

${ }^{82}$ Ibid., pp. 295-296.
} 
divino que, cuando hace su aparición, colapsa todos los ejes ordenadores de la existencia. Un orden personal desde el horizonte de la nada es impensable: aquí no hay ni personas humanas ni divinas, ni nada es debido a un orden personal; aquí no hay designio, ni providencia ni thelos alguno. Paso hacia la nada que en el ser humano acontece como desnudamiento, desasimiento, abandono y silencio. Así que lo que primero es visto como ironía hacia la forma, resulta que, tal y como sucede con Muerte sin fin, tal ironía en realidad se trata de un desnudamiento y destrucción y muerte de lo creído hasta ahora: la idea de Dios, la idea de un orden racional, la idea de la razón, después de lo cual se desoculta "el escenario de la nada" y el silencio. Arturo Cantú señala: "Aunque la desaparición del mundo es simultánea a la desaparición de la forma, el poeta hace desfilar a todos los seres, según su clase, en su camino hacia la nada". ${ }^{83}$ Este procedimiento es un itinerario, una travesía o viaje realizado meticulosamente, si no se da la muerte de la forma, no se da la muerte del mundo; si no se da la muerte del mundo, no se da la muerte de Dios; si no se da la muerte de Dios, no se da la muerte de la razón; si no se da la muerte del yo-razón, no se da el desocultamiento del horizonte de la nada que lleva a "una nada más estéril, agria [...] que reconcentra su silencio blanco/ en la orilla letal de la palabra/ y en la inminencia misma de la sangre" como leemos en el cuarto poema. La desestructuración del simbólico mundo occidental DIOS-YO-MUNDO conduce inevitablemente a abandonar la cima del yo o la cima de Dios o la cima del poder del ente. Ya sin cimas, sólo se escucha un inmenso silencio donde al fin todo muere y está muriendo sin excepción. Este verdadero modo de ser del ser no puede ser realizado sino por una conciencia descreída, escéptica, que por serlo ya ha avanzado a la desposesión y a la despersonalización. Descree de la posibilidad de apropiación, porque descree de los modos del ser y de sus atributos, descree de su posibilidad de aprehensión, porque en la vida muriéndose, "muerte viva", en suma, no hay nada que aprehender. En este sentido, la poesía desoculta el ser en cuanto tal y en su totalidad desde el encuentro con la muerte y en convivencia con la nada. La nada, la muerte, en un sentido radical es la casa del ser. La poesía de Gorostiza se ha encargado de desocultar el asiento de todas las cosas humanas y no humanas: la nada, la muerte y el vacío. Cuando alcanza el lugar sin referencias que es la nada, el descampado, Muerte sin fin entonces nos sumerge en otro modo de ser o en el verdadero modo de ser, es decir, liquida la raíz del cálculo y del dominio del ente. En la poesía de Gorostiza más originario que Dios es la nada, en la cual el mismo Dios flota, como si en la nada "hubiese al fin ahogado su palabra sangrienta". Y esto no es decir cualquier cosa. Quiere decir que con él desaparece el pecado y la concomitante amenaza del infierno y del juicio final.

${ }^{83}$ Ibid., p. 293. 
Es entonces que viene el segundo aleluya de la obra, "ALELUYA ALELUYA", dice Gorostiza. Este aleluya anuncia por fin la posibilidad de afirmación. Por eso en el último poema se inicia con el verso

¡Tan tan! ¿Quién es? Es el Diablo, es una espesa fatiga, un ansia de trasponer estas lindes enemigas, este morir incesante, tenaz, esta muerte viva, ${ }^{84}$

Debicki señala: "El llamar a la puerta indica una interrupción de la situación anterior". ${ }^{85}$ Pero dicha interrupción no consiste en una simple vuelta a la existencia física y a los instintos, representados en la figura del Diablo, sino que la interrupción acontece porque aparece una nueva comprensión del ser. Con toda razón. Una vez que Dios flota en las aguas de la nada, desde sus astillas, "este morir incesante, tenaz, esta muerte viva" es lo que hace también el aparecer de "una ciega alegría", también "disfrutarnos enteros en sólo un golpe de risa" y también hace posible "el gusto/ que tomamos en morirla" como se lee en el décimo poema. Es decir, la muerte me acecha y me asesina, pero también, también me enamora, por lo cual Gorostiza, en un movimiento afirmativo final, ${ }^{86}$ le dice a la muerte viva: "iAnda, putilla del rubor helado,/ anda, vámonos al diablo!”, así como el más feo de los hombres hacia el final de Así habló Zaratustra le dice a la vida: “Esto era la vida pregunto yo a la muerte? Bien, otra vez". El baile va pues aparejado con la muerte, el ser con la nada, la forma con la no forma, sí de manera trágica y autocontradictoria. ${ }^{87}$

${ }^{84}$ A. Cantú, op. cit., p. 52.

${ }^{85}$ A. Debicki, op. cit., p. 100.

${ }^{86}$ Para Elías Nandino, José Gorostiza "vuelve su poema un poema circular, repetitivo, casi un callejón sin salida o un laberinto sin hilo de Ariadna, del cual trata de salirse o de resolverlo, pero, entonces, cae a su propio remolino, y que, al irlo a engullir, inventa luego una salida [...] para lograr salir y pisar tierra firme" (Elías Nandino, "Pepe Gorostiza y su talón de Aquiles", en J. Gorostiza, Poesía y poética, p. 306).

${ }^{87}$ Según Silvia Pappe, para Elsa Dehennin en su libro Antithése, oxymore et paradoxisme: aproches rhétoriques de la poésie de José Gorostiza, Gorostiza a través de la antítesis, el oxímoron y la paradoja, nos conduce a una posición vital a "la aceptación de la muerte viva, de la coexistencia de contrarios inseparables e inconciliables". Se trata de una sabiduría humana, que "lejos de abandonarse a la muerte, se instala en la ambigüedad, en la paradoja de un grito irracional: 'es amando la muerte que el hombre honra la vida'”. (Cf. Silvia Pappe, "Destinos", en J. Gorostiza, Poesía y poética, p. 207). 